\title{
Adoption of Latin Square Experimental Design in Minimizing Cheating During Examination
}

\author{
Kayode Ayinde \\ Department of Statistics \\ Ladoke Akintola University of Technology \\ P.M.B.4000, Ogbomoso, Oyo State, Nigeria
}

\begin{abstract}
Sitting arrangement of students during examination has been observed as a fundamental factor that can influence or aid cheatings/examination malpractices. This paper therefore proposed and investigated statistically some methods of overcoming the problem of sitting arrangement, and thus reduces examination malpractice especially when examination questions are basically objective. The first method requires dividing the $n$ number of questions into $p$ groups, $p \leq n$, such that the first question in each group has all the information needed to answer other questions which may be in the group. The second method requires using the number of different options $(p)$ in a question instead of dividing the $n$ number of questions into $p$ groups. In each method, a $p \times p$ Latin Square Design is then formed from which $k$ blocks are randomly chosen, $2 \leq k \leq p$. The order of arrangement in each $i$ block $i=1,2, \ldots, k$; is then followed to re-organize the questions/options into $k$ different groups/types of questions. The question papers after printing are arranged and parceled such that a question paper from each $i$ different group/type of questions is allowed to follow each other. The other proposed method is a combination of the two methods to form a two factor experimental design. Statistical investigations of these methods revealed that the students are not at any disadvantage in term of their performances as a result of different re-arrangements of questions. The methods are thus recommended for usage.
\end{abstract}

\section{General Terms}

Minimizing Examination Malpractices

\section{Keywords}

Questions, Examination Mal-practices, Latin Square Design, Factorial Experiments

\section{INTRODUCTION}

One of the objectives of education is to prepare the young ones to face future challenges and develop them to meet the nation's man power requirement. Examination remains a fundamental medium through which this objective can be assessed [1]. Examination has been defined as a way to ascertain how much of a subject matter in a particular field of study a candidate has mastered [2]. It has also been defined as the process through which students are evaluated or tested to find out the quality of knowledge they have acquired within a specified period [3].

Examination could be oral, written or both; it could be internal or external. Examples of internal examination are continuous assessment tests and annual or promotion examinations. Examples of bodies that conduct external (public) examinations for schools especially in Nigeria are West African Examination Council (WAEC), National Examination Council (NECO), Joint Admission Matriculation Board (JAMB), National Teachers' Institute (NT) and National Business and Technical Examination Board (NABTEB). Objective questions are often set by these bodies in their examinations to assess the students.

Examination is never free from problems. Examination malpractice is one of these significant problems that are presently challenging education system nowadays. It is anything that is done wrongly before, during and even after the examination. [4]. It occurs both in internal and external examinations. Nwana [5] stated examination malpractice as massive and unprecedented abuse of rules and regulations pertaining to internal and public examinations, beginning from setting of questions through the taking of the examinations, their marking and grading, to the release of the results and the issuance of certificates. Examination malpractice has also been defined as an act of wrong doing carried out by a candidate or groups of candidates or any other person with the intention to cheat and gain unfair advantage in an examination. It may involve students, teachers (lecturers), parents, school heads, invigilators, supervisors, attendants and any other examination officer [6]. Ruwa [7] traced back examination malpractice to 1914 . He further reported that in University of Maiduguri in Nigeria, about $25 \%$ of the students interviewed admitted to have engaged in one form of examination malpractice or the other. The instances of examination malpractice vary, it can be in form of impersonation, leakage of questions, tampering with results, computer frauds of divers forms, fraudulent practices by invigilators, officials and security personnel charged with supervising examinations, body writing or tattoo in which students especially females ones keep some materials in hidden parts of their bodies, submission of new answer scripts, change of examination score or grade and so on $[8,9$, $10,11,12,13,14]$. Afigbo [15] called examination malpractice a demon with thousand faces.

Reasons for its prevalence are traceable to many factors including inadequate funding of schools [16], laxity in prosecuting offenders [17], inability of students to cope with school work, students' inadequate preparation and strong desire to pass at all costs, sitting arrangement of students during examinations, too much emphasis on certificate, and non-completion of subject syllabuses [13, 18 and 19].

The situation of examination malpractice is so embarrassing to Nigeria as a nation that the federal military government in 1984, promulgated Decree 20 to deal with it. The Decree read thus:

"Any person who fraudulently or with the intent to cheat or secure any unfair advantage to himself or any other person or in abuse of his office, produces, sell or buy any question 
paper intended for the examination of persons at any examination or commit any of the offences specified in section 3 (27) (c) of this Decree, shall be guilty of the offence and on conviction be sentenced to 21 years imprisonment...[20]".Due to inability of the government to enforce this Decree, this position was revised in examination malpractice Act 33 of 1999 and the punishment stipulated as a fine ranging from a fine of N50,000.00 to N100,000.00 and imprisonment for a term of 3-4years with or without option of fine. Hitherto, examination malpractice is still a major menace to the Education System and the consequences are long standing global problems which include production of half-baked graduates [21 and 22].

In short, it has become a plague, an epidemic and a great problem in national examination system [23 and 24] which needs prompt attention even though it is believed that it will be difficult to get it eradicated [4].

Several methods have been introduced in the recent times to reduce examination malpractice. Efforts reported include public enlightenment campaigns, information to students on rules and regulation guiding examinations, punitive action against anyone involved in examination malpractice whether directly or indirectly and continuous assessment [14]. When questions are objective, one of the methods for reducing examination malpractice during the conduct of the examination involves randomly selection of questions (using computer) from a large volume of questions in which case, questions answered by one student are most likely to be different from the other students. As good as this technique is, it has some limitations. One of them is that the students are not being examined using the same questions since the questions being answered by the students cannot be equally tough. Also, when the students are to answer the question using computer, one is in doubt as to whether the students' knowledge of the course / discipline is what is being examined or his /her knowledge of computer. A student can be very good in a course but does not have the knowledge of computer operation. Another method being used by JAMB in conducting Unified Tertiary Matriculation Examination (UTME) in the recent times involves setting different types of questions for students with the type specified as a question among the examination questions. The students are therefore expected to shade the type of question they answered. This is also a good technique but it appears students may still not be answering same questions. Moreover, the students are conscious of the type of questions being answered. Consequently in this paper, some methods which take into consideration some of these vital demerits are proposed. The methods are further investigated statistically to ensure that they do not in any way influence the performances of the students.

\section{THE PROPOSED METHODS}

The methods proposed here are as a consequence to the wrong belief of students reported by Alutu and Aluede [4] that examination ethics entail, among others, sitting next to someone in order to copy from his or her paper in the examination hall. Thus, sitting arrangement during examination can influence or aid examination malpractice; and so to disorganize any formation that could lead to examination malpractice, this paper therefore proposes some methods visa-vice re-arrangement of questions or options of questions.

The first method requires dividing the $n$ number of questions into $p$ groups, $p \leq n$, such that the first question in each group has all the information needed to answer other questions which may be in the group. A $p \times p$ Latin Square

Design is then formed from which $k$ blocks are randomly chosen, $2 \leq k \leq p$. The order of arrangement in each $i$ block $i=1,2, \ldots, k$; is then followed to re-organize the questions into $k$ different groups of questions. The question papers after printing are arranged and parceled such that a question paper from each $i$ different group of questions is allowed to follow each other. They are to be distributed to the students in the examination venue in this order. By this method of questions' re-arrangement, question 1 in group I may be question 10 in group II, question 26 in group III and question 30 in group IV and so on. With this method, students do not only answer the same questions but are forced to be independent since two or three or more students sitting next to each other are not necessarily answering the same kind of question. The second method is similar to the first except that it requires using the number of different options $(p)$ in a question to form a $p \times p$ Latin Square Design instead of dividing the $n$ number of questions into $p$ groups. With this method, students do answer the same questions and even though any two or three or more students seating next to each other with the intention of partaking in examination malpractice may succeed but their success may yield nothing but a failure while the course is graded. The other proposed method is a combination of the two methods to form a two factor experimental design. The methodology first requires the formation of different types of questions using the $k$ number of options. On each $i$ type of questions, the same $k$ randomly chosen blocks, as in the first method, are used to reorganize the questions into $k$ different groups of questions. After printing the question papers in this case, they are arranged and parceled such that a question paper from each $i$ different group of questions follows each other, and thereafter the next different type of questions follows with a question paper from each $i$ different group of questions still follows each other. This continues until all the $k$ different types of questions have been arranged. They are to be distributed to the students in the examination venue in this order. Meanwhile, in all these proposed methods a hidden sign is put to identify each different type of questions.

\section{EMPERICAL AND STATISTICAL INVESTIGATIONS}

In order to investigate the effect of these different formations of question on the performances/ results of the students, STA 207 - "Statistics for Physical Sciences and Engineering Students" offered by five departments of the University namely: Pure and Applied Mathematics, Chemistry, Physics, Science Laboratory Technology and Earth Sciences in Ladoke Akintola University of Technology, Ogbomoso, Oyo State, Nigeria was used. The first, second and the third methods were respectively used to conduct the STA 207 examination in 2009/2010, 2010/2011 and 2011/2012 academic sessions. In 2009/2010 academic session, the objective questions were divided into four (4) different groups. All the four (4) blocks resulting from the $4 \times 4$ Latin Square Design were used to re-structure the questions into four different groups of questions. In 2010/2011 academic session, the five (5) options in a question were used to form a $5 \times 5$ Latin Square Design from which four (4) blocks were randomly chosen using 
computer software, SPSS 16.0. The four (4) blocks were used to re-structure the options of the questions into four (4) different types of questions. In 2011/2012 academic session, all the five (5) blocks resulting from the $5 \times 5$ Latin Square Design were used to re-structure the questions into five different types of questions, and all the five (5) blocks emanating from the five (5) divisions of the questions and $5 \times 5$ Latin Square Design were also used to further restructure the questions in each different type of questions to have the questions re-arranged into five (5) different groups of questions. Thus, the two factor experiment here is $2^{5}$ factorial experiments. In all the three sessions, the questions were arranged, parceled and distributed in the examination hall to the students as earlier discussed.

For the statistically investigations in the first two academic sessions, a random sample of five students that used each of the four (4) kinds of the examination questions was selected from each of the five departments offering the course. In the third academic session, a random sample of five students was selected from each of the twenty five (25) different combinations of groups and types of questions. With SPSS 16.0, a two-way analysis of variance (ANOVA) model was used to examine the effect of the different form of rearrangement of questions or options of the question on the performances of the students.

\section{RESULTS AND DISCUSSIONS}

The summary of results of the first proposed method based on the two way analysis technique is summarized in Table 1:

From Table 1, it can be seen that the main effect of group into which the questions have been re-arranged, departments and their interaction effect are not significant (P-value >0.05). Thus, it can be inferred that neither re-arranging the questions into different groups nor the department which the students belong does have significant influence on the performance of the students.

Table 1: ANOVA Table for the first method showing the effect of the types of question and department on the students' performance

\begin{tabular}{|l|l|l|l|l|l|}
\hline Source & $\begin{array}{l}\text { Type III } \\
\text { Sum of } \\
\text { Squares }\end{array}$ & Df & $\begin{array}{l}\text { Mean } \\
\text { Square }\end{array}$ & F & Sig. \\
\hline Group & 13.950 & 3 & 4.650 & .109 & .954 \\
\hline Department & 367.800 & 4 & 91.950 & 2.162 & .081 \\
\hline $\begin{array}{l}\text { Group* } \\
\text { Department }\end{array}$ & 319.000 & 12 & 26.583 & .625 & .815 \\
\hline Error & 3402.000 & 80 & 42.525 & & \\
\hline Total & 4102.750 & 99 & & & \\
\hline
\end{tabular}

The summary of results of the second proposed method based on the two way analysis technique is summarized in Table 2: From Table 2, it can be seen that the main effect of question types, departments and their interaction effect are also not significant (P-value >0.05). Thus, it can be inferred that neither re-arranging the options of the questions into different types nor the department which the students belong does have significant influence on the performance of the students.
Table 2: ANOVA Table for the second method showing the effect of the types of question and department on the students' performance

\begin{tabular}{|l|l|l|l|l|l|}
\hline Source & $\begin{array}{l}\text { Type III } \\
\text { Sum of } \\
\text { Squares }\end{array}$ & Df & $\begin{array}{l}\text { Mean } \\
\text { Square }\end{array}$ & F & Sig. \\
\hline Type & 142.760 & 3 & 47.587 & 1.147 & .335 \\
\hline Department & 163.140 & 4 & 40.785 & .983 & .421 \\
\hline $\begin{array}{l}\text { Type* } \\
\text { Department }\end{array}$ & 384.540 & 12 & 32.045 & .773 & .676 \\
\hline Error & 3317.600 & 80 & 41.470 & & \\
\hline Total & 4008.040 & 99 & & & \\
\hline
\end{tabular}

Also from Table 3, it can be seen that the main effect of rearranging the questions to form groups, interchanging the options to form different types of question and their interaction effect are also not significant (P-value >0.05). Thus, it can be inferred that neither re-arranging to form different groups nor re-arranging the options to form different type of questions does have significant influence on the performance of the students.

Table 3: ANOVA Table for the third method showing the effect of the groups of question and types of question on the students' performance

\begin{tabular}{|l|l|l|l|l|l|}
\hline Source & $\begin{array}{l}\text { Type III } \\
\text { Sum of } \\
\text { Squares }\end{array}$ & Df & $\begin{array}{l}\text { Mean } \\
\text { Square }\end{array}$ & F & Sig. \\
\hline Group & 70.560 & 4 & 17.640 & .964 & .431 \\
\hline Type & 109.040 & 4 & 27.260 & 1.489 & .211 \\
\hline $\begin{array}{l}\text { Group* } \\
\text { Type }\end{array}$ & 278.800 & 16 & 17.425 & .952 & .514 \\
\hline Error & 1830.400 & 100 & 18.304 & & \\
\hline Total & 2288.800 & 124 & & & \\
\hline
\end{tabular}

\section{CONCLUSION AND RECOMMENDATION}

Even though the methodology of having this kind of question set for an examination is tasking and very demanding, the proposed methods have independently and evidently shown that they do not affect the performances of the students. Also, the performances of the students have been observed not to be influenced by the departments they belong. The interaction effects of the each method and the department or a combination of the two methods have also not influenced the students' performance. Consequently, the proposed methods are hereby recommended for use to reduce examination malpractice which could have occurred as a result of sitting arrangement especially when questions are basically objective.

\section{REFERENCES}

[1] Jimoh, B. O. 2009. Examination malpractice in secondary schools in Nigeria: What sustain it? European Journal of Education 1 (3), $101-108$. 
[2] Maduka, C. 1993. Examination Malpractice: Causes, Implications and Remedies. Benin City, Amik Press.

[3] Balogun, J. O. 1999. Examination Malpractices and the Nigeria Society. The Journal of Education, 4(1), 110116

[4] Alutu, A. N. G. and Aluede, O. 2006. Secondary school students' perception of examination malpractices and examination ethics. Journal of Human Ecology, 20(4), $295-300$.

[5] Nwana, O.C. 2000. Aberrations in the Nigerian Education System in the state of education in Nigeria UNESCO, Abuja Office, Nigeria.

[6] Odongbo, D. N. 2002. Controlling Examination Malpractice and irregularities; Uganda National Examination Board's Experience. Proceedings of the $20^{\text {th }}$ Annual Conference of AEAA, Arusha, Tanzania.

[7] Ruwa, M. 1997. Examination Malpractice. A case study of the University of Maiduguri. Maiduguri Journal of Educational Studies, 1(1), 25 - 30

[8] Abba, A. 1997. The University environment and examination. A paper presented at a seminar on examination ethics held at University of Maiduguri $3^{\text {rd }}-$ $4^{\text {th }}$ September

[9] Afolabi, A. 1998. Validity of Public Examination, the Environment and Sustainable Development. Book of readings on education, environment and sustainable national development, Ife social educators, published by Cardinal Crest Ltd.

[10] Maduabum, M. A. 1998. Examination Malpractices in Nigeria Education System: Perspectives and Possibilities.

[11] Ojerinde, D. 2004. Examination Malpractice in our Educational System - the NECO Experience. A Faculty of Education Lecture delivered at the Obafemi Awolowo University, Ile-Ife on $23^{\text {rd }}$ February.

[12] Jacob, S. and Lar, T. D. 2001. Forms and reasons for examination malpractice: Implication for National Development. Proceeding of the $16^{\text {th }}$ Annual Congress of the Nigeria Academy of Education, 355 - 365.
[13] Balogun, J. O. 1999. Examination Malpractices and the Nigeria Society. The Journal of Education, 4(1), 110116

[14] Fagbemi, A. 2001. Assessment and Education Malpractices. The Nigeria Academy of Education p. 82 100.

[15] Afigbo, A. E. 1997. The demon with a thousand faces: Examination malpractices in historical perspectives. The challenge of a collective responsibility, p.13 -22

[16] Maduabum, M. A. and Maduabum, C. I. 1998. Examination Malpractices and Standards: Reflection on Society, Institution and teacher-related factors.

[17] Uwadiae, I.J. 1997. School factors as determinants of examination malpractice in the secondary school mathematics examination in Nigeria. Unpublished Ph. D. Thesis, University of Ibadan, Ibadan.

[18] Obe, E. C. 1998. An appraisal of continuous and national examinations in Nigerian schools. Inaugural Lecture Series, Lagos. University of Lagos Press.

[19] Onyechere, I. 1996. Examination ethic handbook Examination Ethic Project, Lagos, Nigeria.

[20] Fagbemi, A. 1998. Assessment and Education Malpractices. Proceeding of the $16^{\text {th }}$ Annual Congress of the Nigeria Academy of Education, Jos, p. $82-100$.

[21] Balogun, J.O. 1995. Towards minimizing examination misconducts in the Nigerian School System. A paper presented at a seminar on towards improving the qualities of education in Nigeria. School of Education F.C.E. Panksbin.

[22] Alonge, M.S. 2002. Assessment and Examination: The Pathways to educational development. An inaugural Lecture presented at the University of Ado-Ekiti.

[23] Olayinka, M.S. 1996. Guidance and Counseling Approaches to Examination Malpractice Lagos. Premier Press.

[24] Kolo, Z.N. 1999. Examination Malpractice among secondary students. A paper presented at the first national conference of school of Education, College of Education, Ilorin. 